\title{
Organizational leadership perspectives in implementation of the One Health approach: A case of the Zoonotic Disease Unit and core One Health implementers in Kenya
}

\author{
Thomas Manyibe Nyariki ${ }^{1}$, Mathew Muturi ${ }^{2}$, Athman Mwatondo ${ }^{2}$, Michael Cheruiyot ${ }^{3}$, Harry Oyas ${ }^{3}$, Vincent Obanda ${ }^{4}$ \\ Francis Gakuya ${ }^{4}$, Rees Murithi Mbabu ${ }^{3}$ and Mercy Muthoni Mugambi ${ }^{1}$
}

1. Department of Extra Mural Studies, University of Nairobi, Main Campus, P. O. Box 30197-00100, Nairobi, Kenya; 2. Zoonotic Disease Unit, KNH Compound, NASCOP Ground, Opp. Afya, P.O. Box 20811-0020, Nairobi, Kenya; 3. State Department of Livestock, Ministry of Agriculture Livestock and Fisheries, Office of the Director of Veterinary Services, Veterinary Research Laboratories, Private Bag, Kabete, Kangemi 00625, Nairobi, Kenya; 4. Kenya Wildlife Services, P.O. Box 40241-00100, Nairobi, Kenya.

Corresponding author: Thomas Manyibe Nyariki, e-mail: nyarikitom@gmail.com

Co-authors: MM: muturimathew@gmail.com, AM: amwatondo@yahoo.com, MC: drmkcheruiyot@gmail.com,

HO: harryoyas@yahoo.com, VO: vobanda@gmail.com, FG: gakuya@kws.go.ke,

RMM: murithi.mbabu@gmail.com, MMM: mugambimercy@yahoo.com

Received: 15-08-2017, Accepted: 14-09-2017, Published online: 17-10-2017

doi: 10.14202/IJOH.2017.57-65 How to cite this article: Nyariki MT, Muturi M, Mwatondo A, Cheruiyot M, Oyas $H$, Obanda V, Gakuya F, Mbabu RM, Mugambi MM. Organizational leadership perspectives in implementation of the One Health approach: A case of the Zoonotic Disease Unit and core One Health implementers in Kenya. Int J One Health 2017;3:57-65.

\begin{abstract}
Aim: This study examined organizational leadership as a cross-sectoral collaboration factor in the implementation of the One Health $(\mathrm{OH})$ approach using Kenya's Zoonotic Disease Unit and its core $\mathrm{OH}$ implementers as an example.

Materials and Method: The study used a mixed methods research design. A semi-structured questionnaire was administered to 71 respondents, and key informants were interviewed using an interview guide. All the seven key informants and 53 (74\%) of the respondents participated in the study. Data were checked for consistency, coded, entered into the Statistical Package for the Social Sciences, and analyzed using descriptive and correlational statistics. Interview data were transcribed and analyzed thematically.

Results: From the analysis, 41/53 (77.2\%) of the respondents were senior personnel, 51/53 (85\%) of them had worked for 5 years and above in their organizations, and 38/53 (71.7\%) had at least a Master's degree. The study established that although most leaders in the organizations had embraced the $\mathrm{OH}$ approach, they were not actively involved in its implementation due to constraints such as inadequate funding. There were moderate and statistically significant positive correlations between participation in leadership roles in implementing the $\mathrm{OH}$ approach and the level of awareness $(\operatorname{Rs}(51)=0.54, \mathrm{p}<0.001)$ as well as level of sensitization ( Rs $(51)=0.52, \mathrm{p}<0.001)$. Majority $(86 \%)$ of respondents acknowledged that top government leaders were not well sensitized about the $\mathrm{OH}$ approach.
\end{abstract}

Conclusion: Organizational leadership plays an important role in the implementation of the OH approach. However, sensitization of leaders about the $\mathrm{OH}$ approach needs to be enhanced and expanded.

Keywords: cross-sectoral collaboration, One Health approach, organizational leadership, sensitization.

\section{Introduction}

In the recent years, emerging diseases with serious socioeconomic consequences have re-awakened the global community to the need for cross-sectoral collaboration in addressing health matters [1-3]. The Ebola outbreak in Western Africa, for instance, costed over USD 6 billion in direct expenses and at least USD 15 billion in indirect economic losses by March 2015 [4]. The World Bank (2012) estimates the potential economic impacts of an influenza pandemic involving 71 million human fatalities or $1 \%$ of the global population at USD 3 trillion. These examples

Copyright: Nyariki, et al. This article is an open access article distributed under the terms of the Creative Commons Attribution 4.0 International License (http://creativecommons.org/licenses/ by/4.0/), which permits unrestricted use, distribution, and reproduction in any medium, provided you give appropriate credit to the original author(s) and the source, provide a link to the Creative Commons license, and indicate if changes were made. The Creative Commons Public Domain Dedication waiver (http:// creativecommons.org/ publicdomain/zero/1.0/) applies to the data made available in this article, unless otherwise stated. underscore the need for effective strategies to address such diseases. About $75 \%$ of emerging diseases are zoonotic, meaning that they can be naturally transmitted from vertebrate animals to humans and vice versa [5]. These diseases emerge due to factors such as ecosystem change, industrial development, social inequalities, and climate change that are linked to human population growth [6-8]. Several sectors, ministries, and disciplines must, therefore, collaborate to prevent and control these diseases and to achieve optimal health for people, animals, and the ecosystem [9]. Weak collaboration across sectors in addressing health matters has been recognized as a global issue $[1,10]$. This weakness is based on entrenched organizational cultures [11]. There has, therefore, been increasing global advocacy for the use of collaborative approaches in addressing health issues in what is currently known as the One Health $(\mathrm{OH})$ approach $[1,9]$.

Despite increasing global momentum of the $\mathrm{OH}$ approach, there are relatively few practical examples 
of long-term commitment to and progress in its implementation at national and grass-root levels $[2,12]$. Various authors have stated the need to generate more evidence to inform concrete policy shifts toward adoption of $\mathrm{OH}$ approach at these levels [2,13]. Diverse factors such as awareness, leadership, technical capacities, and policies influence intersectoral collaboration [14-16]. Knowledge of how these factors influence implementation of the $\mathrm{OH}$ approach can contribute to the evidence that is needed to inform policy shifts toward practical adoption of the approach.

The current study focused on the Zoonotic Disease Unit (ZDU) of Kenya and its core $\mathrm{OH}$ implementers. The ZDU, which has been documented as a successful national $\mathrm{OH}$ coordination Unit [17], was established through a memorandum of understanding between the Ministry of Health (MOH) and Ministry of Agriculture Livestock and Fisheries (MALF) in 2011. It currently has a permanent staff of two personnel comprised one medical epidemiologist and one veterinary epidemiologist from the respective ministries. The unit is the secretariat for the Zoonotic Diseases Technical Working Group (ZDTWG) which is the oversight committee for the $\mathrm{OH}$ approach in Kenya. The ZDTWG is being reviewed to become the $\mathrm{OH}$ Technical Committee. The core implementing arms of ZDU are departments or divisions in the MOH and MALF and the Veterinary Services Department of Kenya Wildlife Service (KWS), a parastatal in the Ministry of Environment and Natural Resources (MENR). Other institutions are also engaged with ZDU through the ZDTWG. The aim of this study was to determine how organizational leadership as a cross-sectoral collaboration factor influences implementation of the $\mathrm{OH}$ approach by ZDU and its core implementers.

\section{Materials and Methods}

\section{Ethical approval}

Ethical approval for the study was obtained from the National Commission for Science, Technology and Innovation and the Kenyatta National Hospital and University of Nairobi (UON) Ethic and Research Committee.

\section{Study design}

The study used a mixed methods research design. It targeted technical personnel at the national level in the Directorate of Medical Services (DMS), the Directorate of Veterinary Services (DVS), and the KWS. Within each of these organizations, the study further focused on the departments/divisions that the ZDU recommended as being most relevant and directly engaged with it in the implementation of $\mathrm{OH}$ approach activities. Outside these organizations, three other $\mathrm{OH}$ implementing organizations were selected as sources of key informants to enrich and cross-validate the study. These were the UON's School of Public Health; the UON Faculty of Veterinary Medicine; and the Department of Wildlife Conservation and Management in the MENR.
The target population was 94 personnel, and a sample size of 78 was determined using the Yamane Taro formula. The sample comprised 71 respondents and 7 key informants. Key informants were selected purposively based on expert opinion, whereas respondents were selected using stratified random sampling technique. The research tools, comprising a semi-structured questionnaire and an interview guide, were validated through critique by three senior researchers from the University of Nairobi (UON) and four senior government personnel involved with the $\mathrm{OH}$ approach, before administration. Data were checked for consistency, coded, entered into the Statistical Package for the Social Sciences, and analyzed using descriptive and correlational statistics.

\section{Results}

All seven key informants and 53/71 (74\%) of the respondents participated in the study. Demographic and professional characteristics of the study participants are summarized in Table-1. From the findings, $37 / 53(69.8 \%)$ of respondents were males, and $16 / 53(30.2 \%)$ were females. Further, 41/53 (77\%) of them were aged 36 years, and above, 51/53 (85\%) had served for 5 years and above in their respective organizations, and $41 / 53(77 \%)$ of them were senior staff. In terms of academic qualifications, 13/53 (24.5\%) had bachelor's degrees, 32/53 (60\%) had master's degrees, 6/53 (11.3\%) had $\mathrm{PhD}$, and 2/53 (3.8\%) had diplomas. The analysis shows that the respondents had the age, longevity of service, seniority, and academic qualifications that would enable them to have well-formed opinions about issues related to their work as well as adequate knowledge and exposure on technical and leadership issues in their fields of work. They would, therefore, be expected to provide reliable opinions regarding organizational leadership in the context of implementation of the $\mathrm{OH}$ approach despite the gender imbalance among them that favored males.

The study sought to establish respondents' levels of awareness about the $\mathrm{OH}$ approach using a selfscore scale comprising: 1: Very low, 2: Low, 3: Average, 4: High, and 5: Very high (Table-2). From the analysis, 23/53 (43.4\%) of the respondents had a high level of awareness, 9/53 (17\%) very high, 16/53 (30.2\%) average, $4 / 53(7.5 \%)$ low, and $1 / 53(1.9 \%)$ very low. This shows that only $5 / 53(9 \%)$ of the respondents had a low or very low level of awareness. The remaining 48/53 (91\%) scored themselves average and above and could, therefore, be considered to have at least a general level of awareness about the $\mathrm{OH}$ approach. Furthermore, 32/53 (60\%) of the respondents scored themselves high or very high, suggesting that they had an in-depth understanding about the $\mathrm{OH}$ approach. Since one would expect knowledge-based workers, as those in the current study, to be conscious of their levels of awareness about any subject, these self-ratings show that most personnel within the divisions/ departments of $\mathrm{MOH}, \mathrm{DVS}$, and KWS studied had a 
Table-1: Demographic and professional characteristics of the study participants.

\begin{tabular}{llc}
\hline Aspect & Categories & Frequency (\%) \\
\hline Gender & Male & $37 / 53(69.8)$ \\
& Female & $16 / 53(30.2)$ \\
Age (years) & $22-35$ & $12 / 53(22.6)$ \\
& $36-45$ & $12 / 53(22.6)$ \\
& $46-55$ & $19 / 53(35.8)$ \\
Job & Above 55 & $10 / 53(18.9)$ \\
designations & Assistant Director to & $25 / 53(47.2)$ \\
& Deputy Director level & \\
& Senior Veterinary, Medical, & $16 / 53(30.2)$ \\
& Clinical, and Public Health & \\
& Officers & \\
& Veterinary Officers & \\
& Veterinary Technologists & $4 / 53(15.1)$ \\
Academic & PhD & $6 / 53(11.3)$ \\
qualifications & & \\
& Master's degree & $32 / 53(60.4)$ \\
& Bachelor's degree & $13 / 53(24.5)$ \\
& Diploma & $2 / 53(3.8)$ \\
\hline
\end{tabular}

Table-2: Respondents' levels of awareness about $\mathrm{OH}$ approach.

\begin{tabular}{lc}
\hline Level of awareness & Frequency (\%) \\
\hline Very low & $1(1.9)$ \\
Low & $4(7.5)$ \\
Average & $16(30.2)$ \\
High & $23(43.4)$ \\
Very high & $9(17)$ \\
Total & $53(100.0)$ \\
\hline
\end{tabular}

$\mathrm{OH}=$ One Health

good level of awareness about the $\mathrm{OH}$ approach. To determine why this was the case, the study sought to know if the respondents had been sensitized about the $\mathrm{OH}$ approach using a yes or no question format (Table-3). From the analysis, $37 / 53(69.8 \%)$ of the respondents indicated that they had been sensitized, while $14 / 53(26.4 \%)$ indicated that they had not been sensitized. A minority of 2/53 (3.8\%) did not respond. These findings confirm that the departments/divisions of $\mathrm{MOH}$, DVS, and KWS targeted for the study were well sensitized and aware about the $\mathrm{OH}$ approach.

The study further sought to establish the levels to which respondents had played leadership roles in the implementation of the $\mathrm{OH}$ approach using a selfscore scale that comprised: 1: Very low, 2: Low, 3: Average, 4: High, and 5: Very high (Table-4). From the findings, $16 / 53(30.2 \%)$ of the respondents scored themselves very low, $5 / 53(9.4 \%)$ scored themselves low, 21/53 (39.6\%) scored themselves average, 9/53 (17\%) scored themselves high, and 2/53 (3.8\%) very high. Majority of the respondents $(42 / 53$ or $79.2 \%$ ), therefore, perceived the extent to which they had played leadership roles in implementation of the $\mathrm{OH}$ approach to be average and below, while the remaining $11 / 53(20.8 \%)$ felt that they had provided significant leadership in the approach having scored themselves high or very high. The proportion (21/53 or $39.6 \%$ ) of respondents scoring themselves average
Table-3: Respondents' states of sensitization about the $\mathrm{OH}$ approach.

\begin{tabular}{lc}
\hline State of sensitization & Frequency (\%) \\
\hline Yes & $37(69.8)$ \\
No & $14(26.4)$ \\
No response & $2(3.8)$ \\
Total & $53(100.0)$ \\
\hline
\end{tabular}

$\mathrm{OH}=$ One Health

Table-4: Respondents' levels of leadership in implementation of $\mathrm{OH}$ approach.

\begin{tabular}{lc}
\hline Level of leadership involvement & Frequency (\%) \\
\hline Very low & $16(30.2)$ \\
Low & $5(9.4)$ \\
Average & $21(39.6)$ \\
High & $9(17.0)$ \\
Very high & $2(3.8)$ \\
Total & $53(100.0)$ \\
\hline
\end{tabular}

$\mathrm{OH}=$ One Health

is problematic to interpret as it could include several groups: Those who were uncertain about the question; those who chose to remain modest about their levels of involvement in leadership roles; those who could not admit their minimal level of involvement; and those who were genuinely involved to an average extent. Nevertheless, the large proportion (42/53 or $79.2 \%$ ) scoring themselves average or below suggests that most of the respondents had not played significant leadership roles in promoting the $\mathrm{OH}$ approach. This is remarkable considering that $41 / 53(77 \%)$ of respondents were senior officers within their respective departments with $25 / 53(47.2 \%)$ of them being at the levels of assistant director and above. This could suggest that leadership involvement in the implementation of the $\mathrm{OH}$ approach remains within a narrow spectrum of personnel in core implementing organizations.

The Spearman's rank order correlation was run to determine relationships between respondents' levels of participation in leadership roles in implementing the $\mathrm{OH}$ approach, their awareness about the approach, their level of sensitization, and their demographic characteristics. There were no significant correlations between respondents' levels of participation in leadership roles in the implementation of the $\mathrm{OH}$ approach and age, length of service, seniority, and academic qualifications. However, there was a moderate and statistically significant positive correlation between the levels to which respondents had played leadership roles in implementation of the $\mathrm{OH}$ approach and their level of awareness $\left(\mathrm{R}_{\mathrm{s}}(51)=0.54, \mathrm{p}<0.001\right)($ Table-5). Similarly, there was a moderate and statistically significant positive correlation between the levels to which respondents had played leadership roles in implementation of the $\mathrm{OH}$ approach and their level of sensitization $\left(\mathrm{R}_{\mathrm{s}}(51)=0.52, \mathrm{p}<0.001\right)$. This shows that leaders who were sensitized about the $\mathrm{OH}$ approach and those who were more aware about it were more 
Table-5: Correlations between leadership involvement, awareness, sensitization, and gender in the $\mathrm{OH}$ approach.

\begin{tabular}{|c|c|c|c|c|}
\hline Spearman's rho & Level of leadership & Level of awareness & State of sensitization & Gender \\
\hline \multicolumn{5}{|l|}{ Level of leadership } \\
\hline Correlation coefficient & 1.000 & $0.530 * *$ & $0.523 * *$ & $-0.286 *$ \\
\hline Significant (two-tailed) & 0.000 & 0.000 & 0.000 & 0.040 \\
\hline $\mathrm{N}$ & 53 & 53 & 53 & 52 \\
\hline \multicolumn{5}{|l|}{ Level of awareness } \\
\hline Correlation coefficient & $0.530 * *$ & 1.000 & $0.552 * *$ & 0.190 \\
\hline Significant (two-tailed) & 0.000 & 0.000 & 0.000 & 0.178 \\
\hline $\mathrm{N}$ & 53 & 53 & 53 & 52 \\
\hline \multicolumn{5}{|l|}{ State of sensitization } \\
\hline Correlation coefficient & $0.523 * *$ & $0.552 * *$ & 1.000 & 0.046 \\
\hline Significant (two-tailed) & 0.000 & 0.000 & 0.000 & 0.748 \\
\hline $\mathrm{N}$ & 53 & 53 & 53 & 52 \\
\hline \multicolumn{5}{|l|}{ Gender } \\
\hline Correlation coefficient & $-0.286 *$ & 0.190 & 0.046 & 1.000 \\
\hline Significant (two-tailed) & 0.040 & 0.178 & 0.748 & 0.000 \\
\hline $\mathrm{N}$ & 52 & 52 & 52 & 52 \\
\hline
\end{tabular}

**Correlation is significant at the 0.01 level (two-tailed). *Correlation is significant at the 0.05 level (two-tailed). $\mathrm{OH}=$ One Health

likely to be the ones also playing leadership roles in implementing the approach. These associations underscore the importance of sensitization of leaders in the implementation of the $\mathrm{OH}$ approach. Further, there was a weak but statistically significant negative correlation between respondents' levels of participation in leadership roles in the implementation of the $\mathrm{OH}$ approach and their gender ( $1=$ male and $2=$ female $)$ $\left(\mathrm{R}_{\mathrm{s}}(51)=0.29, \mathrm{p}=0.023\right)$. This reflects a gender imbalance favoring male personnel in playing leadership roles in implementing the $\mathrm{OH}$ approach.

To gain deeper insight into the leadership roles that respondents played in implementing the $\mathrm{OH}$ approach, they were asked to state this using an open question format and the data were analyzed thematically (Table-6). This question was answered by 34 respondents, most likely those who felt that they were significantly engaged in leadership capacities in implementing of the $\mathrm{OH}$ approach. Based on the analysis, $15 / 34(44.1 \%)$ stated that they had played leadership roles in planning and implementing joint disease preparedness and response activities. A further 10/34 (29.4\%) indicated that they had undertaken training and (or) sensitization of personnel on the $\mathrm{OH}$ approach. Others reported their participation in setting up of the ZDU (7/34 or $13.2 \%)$ and others in advocating for the $\mathrm{OH}$ approach $(2 / 34$ or $3.8 \%)$. The findings show that personnel in target organizations had played $\mathrm{OH}$ leadership roles mostly in the areas of planning and implementation of disease preparedness and response and in training and sensitizing staff on the $\mathrm{OH}$ approach while a few had been engaged in advocacy or setting up institutional mechanisms for the $\mathrm{OH}$ approach.

To complement the data on leadership roles played by respondents, the study asked the latter to state how other leaders had influenced them in implementing the $\mathrm{OH}$ approach. This was intended to get a more holistic picture of leadership by examining respondents' perceptions about other leaders.
Table-6: Roles of respondents in implementation of the $\mathrm{OH}$ approach.

\begin{tabular}{lc}
\hline Leadership roles & Frequency (\%) \\
\hline $\begin{array}{l}\text { Planning and implementing joint } \\
\text { disease prevention and response }\end{array}$ & $15(44.1)$ \\
Training and sensitizing staff on $\mathrm{OH}$ & $10(29.4)$ \\
Setting up of ZDU & $7(20.6)$ \\
Advocating for OH & $2(5.9)$ \\
Total & $34(100.0)$ \\
\hline
\end{tabular}

$\mathrm{OH}=$ One health, ZDU=Zoonotic Disease Unit

The results of the thematic analysis are presented in Table-7. From the findings, 38/53 (53.8\%) of the respondents indicated that other leaders had influenced them minimally in the implementation of $\mathrm{OH}$ approach. Conversely, 15/53 (28.3\%) of the respondents indicated that other leaders in their organizations had given them opportunities to participate in $\mathrm{OH}$ approach activities such as conferences and workshops, while 10/53 (18.9\%) indicated that other leaders had contributed to their levels of awareness and knowledge about the $\mathrm{OH}$ approach. The remarkable proportion ( $38 / 53$ or $53.8 \%$ ) of respondents stating that other leaders had influenced them minimally toward implementation of the $\mathrm{OH}$ approach compares favorably with the large proportion $(42 / 53$ or $79.2 \%)$ of respondents who scored themselves average or below with regard to their levels of individual engagement in leadership roles in implementation of the $\mathrm{OH}$ approach. These findings further suggest that leadership involvement in the $\mathrm{OH}$ approach is limited.

The leadership roles stated by the respondents were supported by the key informants. For instance, asked to explain how as a leader, he was involved in the implementation of the $\mathrm{OH}$ approach, one of the key informants related with enthusiasm the role he had played in the formation of the ZDU:

"How I am involved? In a very big way! I am a founder member of the One Health unit-the Zoonotic Disease Unit which is at ...we put it 
Table-7: Respondents' views on how other leaders influence them in the $\mathrm{OH}$ approach.

\begin{tabular}{lc}
\hline Influence of other leaders & Frequency (\%) \\
\hline Minimally or none & $38(53.8)$ \\
Giving respondents opportunities for & $15(28.3)$ \\
participation & $10(18.9)$ \\
$\begin{array}{l}\text { Providing knowledge and awareness } \\
\text { creation }\end{array}$ & $53(100.0)$ \\
Total & \\
\hline
\end{tabular}

$\mathrm{OH}=$ One Health

on Kenyatta National Hospital grounds for the purpose of having a central place ...I don't know whether any of you knows that that unit does not belong to any particular ministry. It does not belong to health nor does it belong to agriculture...it is a unit which was crafted to be in between to coordinate ...coordinate the activities of One Health in Kenya..."

The key informants underscored more roles that they had played in the implementation of the $\mathrm{OH}$ approach. These included: Chairing or participating in various oversight and coordination mechanisms of the $\mathrm{OH}$ approach; advocating for policy changes in support of $\mathrm{OH}$ approach; overseeing development of curricula and co-teaching programs on $\mathrm{OH}$ approach; developing $\mathrm{OH}$ workforce through pre- and post-service training; motivating staff and students to embrace the $\mathrm{OH}$ approach; simplifying bureaucracy in the collaborating organizations and departments; putting in place structures for continuity of the $\mathrm{OH}$ approach; ensuring that all departments were included in the $\mathrm{OH}$ approach; and coordinating $\mathrm{OH}$ activities of core ministries and partners. One key informant explained how cooperative leadership in $\mathrm{OH}$ approach was being exercised through rotational chairing of the ZDTWG, an organ which brings together the core implementing ministries, agencies, academia, private sector, NGOs, and development partners involved in the $\mathrm{OH}$ approach in Kenya. He stated that:

"The ZDTWG is chaired on alternate basis...one does one year... after a year they switch over. Before we used to say it is co-chaired but we said responsibility has to land somewhere... and again the other aspect of leadership when a letter goes out they use a common letterhead, signed by the two directors...the whole thing is again is ownership. Who owns this thing ...so it does not look like one person owns it ...I mean ...you know the tag of war we normally have on the resources..."

Another key informant related being a member of the highest governing body of the $\mathrm{OH}$ Central and East Africa (OHCEA) that brings together deans/ directors from schools of health and those of veterinary sciences to oversee implementation of the $\mathrm{OH}$ approach in institutions of higher learning in the two regions.

"As Director of School of Public Health, I sit in the summit of OHCEA which is the highest level of OHCEA leadership structure. OHCEA has a board which sits to make recommendations that are ratified at the summit... This is at regional level. At country level we coordinate the activities of OHCEA with the assistance of the focal persons. I have been with OHCEA since its beginning around 2010."

To understand how the various leadership roles influenced implementation of the $\mathrm{OH}$ approach, the study asked respondents to score a set of statements on a five-point Likert scale comprising: 1: Strongly disagree, 2: Disagree, 3: Neither agree nor disagree, 4: Agree, and 5: Strongly agree. The responses were analyzed using percentages (Table-8). From the findings, $72.6 \%$ of the respondents admitted that leaders in their organizations had embraced the $\mathrm{OH}$ approach: $51 \%$ agreed and $21.6 \%$ strongly agreed, whereas $19.6 \%$ were neutral and $7.8 \%$ refuted the statement (3.9\% disagreed and 3.9\% strongly disagreed). Further, $86.3 \%$ of the respondents acknowledged that top government leaders were not well sensitized about the $\mathrm{OH}$ approach: $45.1 \%$ strongly agreed and $41.2 \%$ agreed, whereas 5.9\% were neutral and 7.9\% negated the assertion $(5.9 \%$ disagreed and $2 \%$ strongly disagreed). Further, $36.2 \%$ of the respondents were affirmative (28.8\% agreed and 3.8\% strongly agreed), 44\% were neutral, and $23 \%$ were negative $(9.6 \%$ disagreed and $13.5 \%$ strongly disagreed) of the statement that leaders in their organizations were actively engaged in sensitizing personnel about the $\mathrm{OH}$ approach. Likewise, $36.5 \%$ of the respondents affirmed $(34.6 \%$ agreed and $1.9 \%$ strongly agreed), 38.5\% were neutral, and $22 \%$ refuted $(13.5 \%$ disagreed and $11.5 \%$ strongly disagreed) that leaders in their organizations had influenced personnel to adopt the $\mathrm{OH}$ approach.

Regarding leadership and advocacy for the $\mathrm{OH}$ approach, 41.2\% admitted (35.3\% agreed and 5.9\% strongly agreed), $35.3 \%$ were neutral, and $23 \%$ negated the statement (13.9\% disagreed and $9.8 \%$ strongly disagreed) that leaders in their organizations advocated for allocation of resources for implementation of the $\mathrm{OH}$ approach. On leadership and simplification of bureaucracy, $27.4 \%$ of the respondents acknowledged (23.5\% agreed and 3.9\% strongly agreed), $52.9 \%$ were neutral, and $9.6 \%$ rebutted $(9.8 \%$ disagreed and $9.8 \%$ strongly disagreed) the statement that leaders in their organizations helped to remove bureaucratic barriers to implementation of the $\mathrm{OH}$ approach. Concerning leadership and guidance on the $\mathrm{OH}$ approach, $32.6 \%$ of the respondents admitted (28.8\% agreed and 3.8\% strongly agreed), $42.3 \%$ were neutral, and 25 rejected (17.3\% disagreed and $7.7 \%$ strongly disagreed) the statement that leaders in their organizations advised and guided personnel on practical implementation of the $\mathrm{OH}$ approach. Regarding leadership and creation of team spirit in the $\mathrm{OH}$ approach, $32.6 \%$ of the respondents affirmed (28.8 agreed and 3.8 strongly agreed), $42.3 \%$ were neutral, and $25 \%$ refuted $(17.3 \%$ disagree and $7.7 \%$ strongly disagreed) that leaders in 
Table-8: Summary Likert scores on leadership and implementation of the $\mathrm{OH}$ approach.

\begin{tabular}{|c|c|c|c|c|c|}
\hline Aspects of leadership and implementation of the $\mathrm{OH}$ approach & $5(\%)$ & $4(\%)$ & $3(\%)$ & $2(\%)$ & $1(\%)$ \\
\hline Leaders in my organization have embraced the $\mathrm{OH}$ approach & 21.6 & 51.0 & 19.6 & 3.9 & 3.9 \\
\hline $\begin{array}{l}\text { Leaders in my organization are actively engaged in sensitizing personnel about } \\
\text { the } \mathrm{OH} \text { approach }\end{array}$ & 3.8 & 28.8 & 44.2 & 9.6 & 13.5 \\
\hline Leaders in my organization have influenced personnel to adopt the $\mathrm{OH}$ approach & 1.9 & 34.6 & 38.5 & 13.5 & 11.5 \\
\hline $\begin{array}{l}\text { Leaders in my organization advocate for allocation of resources for } \\
\text { implementation of the } \mathrm{OH} \text { approach }\end{array}$ & 5.9 & 35.3 & 35.3 & 13.7 & 9.8 \\
\hline $\begin{array}{l}\text { Leaders in my organization help to remove bureaucratic barriers to } \\
\text { implementation of the } \mathrm{OH} \text { approach }\end{array}$ & 3.9 & 23.5 & 52.9 & 9.8 & 9.8 \\
\hline $\begin{array}{l}\text { Leaders in my organization advise and guide personnel on practical } \\
\text { implementation of the } \mathrm{OH} \text { approach }\end{array}$ & 3.8 & 28.8 & 42.3 & 17.3 & 7.7 \\
\hline $\begin{array}{l}\text { Leaders in my organization promote team spirit in implementation of the } \mathrm{OH} \\
\text { approach }\end{array}$ & 11.8 & 27.5 & 41.2 & 9.8 & 9.8 \\
\hline Top government leaders are still not well sensitized about the $\mathrm{OH}$ approach & 45.1 & 41.2 & 5.9 & 5.9 & 2.0 \\
\hline Cell average on practical leadership roles* & 5.2 & 29.8 & 42.4 & 12.3 & 10.3 \\
\hline
\end{tabular}

*The averages exclude the first and last statements that do not concern practical roles. $\mathrm{OH}=\mathrm{One}$ Health

their organizations promoted team spirit in the implementation of the $\mathrm{OH}$ approach.

The finding from the Likert scores shows that most respondents believed that leaders in their organizations had embraced the $\mathrm{OH}$ approach. However, fewer respondents could vouch for their leaders on practical aspects of the implementation of the approach such as sensitizing and influencing staff to adopt the approach, advocating for resources for the approach, simplifying bureaucracy, giving technical guidance, and promoting team spirit with regard to the approach. This is demonstrated by the aggregate cell average of $35 \%$ of the respondents who affirmed $(29.8 \%$ agree and $5.2 \%$ strongly agree) the statements on practical leadership roles compared to $42 \%$ of those who were neutral and $23 \%$ who refuted $(12.8 \%$ disagree and 10.3 strongly disagree) the statements. The fact that leaders had embraced the $\mathrm{OH}$ approach and yet were not sufficiently involved in implementing it is a paradox suggesting existence of other inhibitors to practical implementation of the approach. Such inhibitors could include the lack of sensitization of top government leaders on the $\mathrm{OH}$ approach which could be associated with limited resource allocation and a policy environment that does not adequately enable implementation of the approach.

The study sought to understand what could be the most influential leadership roles in the implementation of the $\mathrm{OH}$ approach by asking respondents to state their views, and the data were analyzed thematically (Table-9). Views were given by 46 respondents. The analysis shows that $20 / 46(43.5 \%)$ of them expected successful leaders in the implementation of the $\mathrm{OH}$ approach to develop, empower, and motivate personnel. They explained in various ways that this could be achieved through training, mentorship, provision of growth opportunities to personnel, and rewarding them for their success in implementing $\mathrm{OH}$ activities. A further 15/46 (32.6\%) prioritized planning, organizing, and coordinating $\mathrm{OH}$ programs as the most influential leadership roles. Securing and managing resources was seen by $7 / 53(15.2 \%)$ of the respondents
Table-9: Respondents' views of influential leadership functions in $\mathrm{OH}$ approach.

\begin{tabular}{lc}
\hline Function & Frequency (\%) \\
\hline $\begin{array}{l}\text { Developing/empowering and motivating } \\
\text { staff }\end{array}$ & $20(43.5)$ \\
Planning, organizing, and coordinating & $15(32.6)$ \\
Securing and managing resources for & $7(15.2)$ \\
OH & $4(8.7)$ \\
Influencing policy formulation on $\mathrm{OH}$ & $46(100.0)$ \\
Total &
\end{tabular}

$\mathrm{OH}=$ One Health

as the most important leadership role for implementation of the $\mathrm{OH}$ approach while $4 / 46(8.7 \%)$ felt that influencing policy was the main role of leaders in the approach.

The influential leadership roles in implementation of the $\mathrm{OH}$ approach were supported by the key informants. Most of them asserted that among the most influential leadership roles were first and foremost to gain ownership of the approach, develop a clear vision about it, and then rally others behind the vision. One key informant said:

"You need to be convinced as a leader first before you move on and once you are convinced...you then start pulling others towards the vision".

Most key informants further pointed out that leaders charged with implementation of the $\mathrm{OH}$ approach had to play the following other roles: Create a working environment for personnel to embrace the $\mathrm{OH}$ approach; develop appropriate policies and institutional structures for $\mathrm{OH}$ approach; remove bureaucratic barriers between organizations and departments; create awareness about and expand participation in the $\mathrm{OH}$ approach; ensure good coordination through clear definition and sharing of roles; provide technical oversight, guidance, and advice on all matters regarding the $\mathrm{OH}$ approach; sit in committees and boards on the $\mathrm{OH}$ approach; interact with top government leaders; issue authoritative statements on $\mathrm{OH}$ issues; build trust; create enthusiasm, promote ownership; manage collaborative leadership; mobilize resources for implementation of $\mathrm{OH}$; and advocate for the $\mathrm{OH}$ 
approach. One key informant, making reference to collaborative leadership in establishment of the ZDU explained:

"...we did it in such a way that nobody felt that he owned the unit (more than the other person)... we saw that (such a feeling) would kill it... You know our culture... of in-fighting. The leadership had to look at how to do it in such a way that we don't kill the spirit of collaboration...because you can easily start and then it dies off because some people feel like they are not into it."

The findings on influential leadership roles show that personnel are aware of the roles that leaders in their organizations could play to enhance implementation of the $\mathrm{OH}$ approach. These broadly include inspirational leadership roles such as developing and motivating staff as well as outcome- or task-oriented roles such as planning and resource mobilization.

The study further sought to determine how the current leadership and organization structure for implementation of the $\mathrm{OH}$ approach could be strengthened using an open question format. Respondents views were analyzed thematically (Table-10). Views were provided by 42 respondents. According to $11 / 42(26.2 \%)$ of the respondents, expanding stakeholder participation in the $\mathrm{OH}$ approach was one of the ways of improving current leadership and/or organizational structure for implementation of the $\mathrm{OH}$. The respondents variously explained that such stakeholder expansion should take into account the following: More technical representation and inclusivity in the ZDTWG including greater involvement of the environment and ecosystem sector; considering establishment of a parliamentary $\mathrm{OH}$ committee; and development of clear terms of reference for the $\mathrm{OH}$ technical working group that spell out the roles of each player. Further, 8/42 (19\%) of the respondents recommended strengthening institutional capacities for implementation of the $\mathrm{OH}$ approach including training of personnel from national to county levels on $\mathrm{OH}$ approach, establishing a robust central data handling and information sharing platform for the involved sectors, upscaling biosafety levels and accrediting institutional laboratories of involved sectors, increasing human resources capacities of the ZDU, and establishing interoperative surveillance systems for animal and human health.

In addition, 7/42 (16.7\%) of the respondents proposed various transformative changes to be made to the ZDU and ZTWG including: Empowering the two institutions through legislation; giving ZDU autonomy; transforming ZDU to a parastatal body; elevating ZDU to departmental level within participating institutions; establishing a $\mathrm{OH}$ directorate; and raising ZDU/ZTWG to higher stature such as that of the HIV/ AIDS Control Board. Furthermore, 6/42 (14.3\%) of the respondents suggested that $\mathrm{OH}$ approach should be devolved to the counties and sub-counties to enhance implementation of $\mathrm{OH}$ activities on the ground. Some
Table-10: Suggestions for improvement of current leadership/organization structure for the $\mathrm{OH}$ approach.

\begin{tabular}{lc}
\hline $\begin{array}{l}\text { How to improve leadership } \\
\text { structure }\end{array}$ & Frequency (\%) \\
\hline $\begin{array}{l}\text { Widen stakeholder participation in } \mathrm{OH} \\
\text { approach }\end{array}$ & $11(26.2)$ \\
$\begin{array}{l}\text { Strengthen capacity for OH } \\
\text { implementation }\end{array}$ & $8(19.0)$ \\
Transform ZDU/OH office & $7(16.7)$ \\
Devolve OH to counties & $6(14.3)$ \\
Improve communication structures & $6(14.3)$ \\
Allocate more funds to OH & $4(9.5)$ \\
Total & $42(100.0)$ \\
\hline
\end{tabular}

$\mathrm{OH}=$ One Health, ZDU=Zoonotic Disease Unit

proposed creation of county OH committees or coordination units and scaling up advocacy with county leadership to seek their support for implementation the $\mathrm{OH}$ approach at county levels.

According to $6 / 42(14.3 \%)$ of the respondents, communication structures among $\mathrm{OH}$ stakeholders should be improved taking into account the following aspects: Mechanisms for regular feedback on progress in implementation of the $\mathrm{OH}$ approach; establishment of open communication channels; improving communication among ministries; and enhancing joint planning and implementation of programs among ministries. Finally, 4/42 (7.5\%) suggested that more government funds should be allocated toward implementation of the $\mathrm{OH}$ approach which some proposed could require legislative and policy interventions.

\section{Discussion}

The study established that although leaders in the core $\mathrm{OH}$ implementing organizations believed in the $\mathrm{OH}$ approach, they were involved to an average or low extent in its implementation. Previous studies show that leadership is crucial in creating a strategic climate for implementation and sustainment of evidence-based practices [18]. Leaders also play an important role in improving collaboration across organizations $[14,15]$. Furthermore, they act as effective change agents in cross-organizational partnerships [19]. The weak leadership engagement in the implementation of the $\mathrm{OH}$ approach demonstrated in the current study, therefore, presents a significant gap in sustainable implementation of the approach.

The study found that top government leaders are still not well sensitized about the $\mathrm{OH}$ approach. Harman [20] asserts that successful collaboration typically requires support from political leaders, opinion-makers, and others who control valuable resources and thus give legitimacy to the collaborative process. Inadequate sensitization of top government leaders, therefore, means that buy-in and goodwill for the implementation of the $\mathrm{OH}$ approach from top management are weak which could limit access to resources for its implementation.

The study found that, despite existing constraints, leaders in the organizations influenced the 
implementation of the $\mathrm{OH}$ approach in various ways mostly through, planning and overseeing joint disease surveillance and response activities, training and sensitizing personnel on the $\mathrm{OH}$ approach, advocating for mainstreaming of the $\mathrm{OH}$ approach, and developing institutional structures for its implementation. Capacity building on cross-sectoral leadership skills in the core $\mathrm{OH}$ implementing organizations could, therefore, enhance the roles of senior personnel in promoting implementation of the $\mathrm{OH}$ approach. This conforms to the assertion of Seims et al. [21] that strengthening of leadership and management skills of health personnel plays an important role in improving service delivery outcomes.

\section{Conclusion}

The current study has established that leadership has positively influenced implementation of the $\mathrm{OH}$ approach in Kenya in various ways. However, senior personnel in leadership positions are not adequately engaged throughout the organizations in implementation of the $\mathrm{OH}$ approach possibly due to factors such as inadequate resources, weak implementation frameworks, or simply inadequate understanding of practical aspects of $\mathrm{OH}$ approach. In addition, top government leaders are not sensitized about the approach which could hinder access to resources for implementation of the approach. The study recommends enhancing and widening leadership engagement in the $\mathrm{OH}$ approach and scaling up sensitization of top government leaders on the same. In particular, the study recommends that all personnel in leadership positions, both technical and managerial, in the organizations involved in the $\mathrm{OH}$ approach should be trained on practical application of the $\mathrm{OH}$ approach, given opportunities and resources to support its implementation, and their participation in the approach evaluated periodically as part of their performance contracting.

\section{Authors' Contributions}

TMN: Conception, design, field work, data analysis, and writing manuscript, MMM: Supervision, design and review of the manuscript, MM, AM, MC, FG, VO, RMM, and HO, the study design, and review of the manuscript. All authors read and approved the final manuscript.

\section{Acknowledgments}

The authors would like to thank the Directors of DVSs, DMS, and KWS for authorizing this study in their respective institutions. The authors wish to thank all colleagues that participated in the study in one-way or another. Special mention goes to Drs. Joan Karanja, Lyndah Makayotto, and David Soti of DMS; Dr. Dismas Ongore of School of Public Health, Mr. Manegene from the Department of Wildlife Conservation in the Ministry of Environment and Natural Resources; Prof. Charles Mulei of Faculty of Veterinary Medicine UON; and Prof. Thumbi Mwangi of the Washington State University, for their support and insights. This study was self-funded.

\section{Competing Interests}

The authors declare that they have no competing interests.

\section{References}

1. World Bank. People, Pathogens and Our Planet, The Economics of One Health, World Bank Report No. 69145GLB. Vol. 2. Washington, DC: World Bank; 2012.

2. Rabinowitz PM, Kock R, Kachani M, Kunkel R, Thomas J, Gilbert J, et al. Toward proof of concept of a one health approach to disease prediction and control. Emerg Infect Dis 2013;19:e130265.

3. Bidaisee S, Macpherson CN. Zoonoses and one health: A review of the literature. J Parasitol 2014;2014:874345.

4. Gostin LO, Friedman EA. The sustainable development goals: One-health in the world's development agenda. JAMA 2015;314:2621-2.

5. Graham JP, Leibler JH, Price LB, Otte JM, Pfeiffer DU, Tiensin T, et al. The animal-human interface and infectious disease in industrial food animal production: Rethinking biosecurity and biocontainment. Public Health Rep 2008;123:282-99.

6. Jones KE, Patel NG, Levy MA, Storeygard A, Balk D, Gittleman JL, et al. Global trends in emerging infectious diseases. Nature 2008;451:990-3.

7. Cascio A, Bosilkovski M, Rodriguez-Morales AJ, Pappas G. The socio-ecology of zoonotic infections. Clin Microbiol Infect 2011;17:336-42.

8. Olson SH, Benedum CM, Mekaru SR, Preston ND, Mazet JA, Joly DO, et al. Drivers of emerging infectious disease events as a framework for digital detection. Emerg Infect Dis 2015;21:1285-92.

9. Wilkinson K, Grant WP, Green LE, Hunter S, Jeger MJ, Lowe $\mathrm{P}$, et al. Infectious diseases of animals and plants: An interdisciplinary approach. Philos Trans R Soc B 2011;366:1933-42.

10. FAO, OIE, WHO. The FAO-OIE-WHO Collaboration: Sharing Responsibilities and Coordinating Global Activities to Addresss Health Risks at The Animal-HumanEcosystems Interfaces, A Tripartite Concept Note April; 2010.

11. Degeling C, Johnson J, Kerridge I, Wilson A, Ward M, Stewart $\mathrm{C}$, et al. Implementing a one health approach to emerging infectious disease: Reflections on the socio-political, ethical and legal dimensions. BMC Public Health 2015;15:1307.

12. Little A. One health: From theory to practice. Can Vet J 2012;53:435-6.

13. Okello AL, Bardosh K, Smith J, Welburn SC. One health: Past successes and future challenges in three African contexts. PLoS Negl Trop Dis 2014;8:e2884.

14. Van Gorder C. Working harder at working together: Building collaboration between public health and health care delivery. Front Public Health 2015;3:167.

15. Henry EL. Facilitative Boundary Leadership: Enabling Collaboration in Complex, Multi-Organizational Work, (Unpublished Doctoral Dissertation), Harvard University, Graduate School of Arts and Sciences; 2015.

16. Owusu NO, Baffour-Awuah B, Johnson FA, Mohan J, Madise NJ. Examining intersectoral integration for malaria control programmes in an urban and a rural district in Ghana: A multinomial multilevel analysis. Int J Integr Care 2013;13:7.

17. Mbabu M, Njeru I, File S, Osoro E, Kiambi S, Bitek A, et al. Establishing a one health office in Kenya. Pan Afr Med J 2014;19:106.

18. Aarons GA, Ehrhart MG, Farahnak LR, Hurlburt MS. 
Leadership and organizational change for implementation (LOCI): A randomized mixed method pilot study of a leadership and organization development intervention for evidence-based practice implementation. Implement Sci 2015;10:11.

19. Wooten LP, Anderson L, Pinkerton J, Noll T, Lori J, Ransom S, et al. Strategic Leadership in Healthcare: The Role of Collective Change Agents in Closing the Gap of Healthcare Disparities, Ross School of Business Working
Paper Series, Working Paper No. 1060; 2006.

20. Harman J. Factors Influencing Successful Collaboration: The Case of dKnet, Partnerships, Proof and PracticeInternational Nonprofit and Social Marketing Conference, University of Wollongong, 15-16 July; 2008.

21. Seims LR, Alegre JC, Murei L, Bragar J, Thatte N, Kibunga $\mathrm{P}$, et al. Strengthening management and leadership practices to increase health-service delivery in Kenya: An evidence-based approach. Hum Resour Health 2012;10:25.

$* * * * * * * *$ 